Vol.1 No.1, Spring 2020

\title{
A Comparison of distraction techniques (bubble and cartoon) on reducing chemotherapy induced pain in children with cancer
}

\author{
Mikaeili N ${ }^{1}$, Fathi $\mathrm{A}^{2}$, Kanani $\mathrm{S}^{3}$, Samadifard H.R ${ }^{4 *}$
}

1- Associate Professor of Psychology, University of Mohaghegh Ardabili, Ardabili, Iran.

2- Assistant Professor of Medical, Ardabil University of Medical Sciences, Ardabil, Iran.

3- M.A. of Clinical Psychology, Islamic Azad University, Ardabil branch, Ardabil, Iran.

4- MA Student of Psychology, University of Mohaghegh Ardabili, Iran.

Corresponding Author: Samadifard H.R, MA Student of Psychology, University of Mohaghegh Ardabili, Iran. E-Mail: hrsamadifard@ymail.com

Received: 21 April 2019

Accepted: 18 May 2019

\section{Abstract}

Introduction:: The purpose of the present study was to compare the influence of the two techniques of distraction through watching a cartoon and bubble manufacturing /producing on chemotherapy pain reduction in children suffering from cancer.

Method: The method of the study was pretest and post test experimentation with the control group. The study population included all children with cancer hospitalized in Buali hospital in Ardabil. The subjects were selected through convenience sampling method and were randomly placed in three groups (16 in distraction group watching a cartoon, 16 in bubble manufacturing and 16 in the control group).To collect the data, the Oucher pain tools and fur the more, to create distraction a bubble manufacturing tool and a cartoon CD were used. To analyze the research hypotheses, ANOVA was applied.

Results: Toki test results show that the average score of pain " making bubbles from the group watching cartoons," and mean scores of "both experimental groups in witness group" was significantly higher $(\mathrm{p}<0 / 05)$. These results mean that watching cartoons and making bubbles help to reduce the pain that felt by children during chemotherapy. Also results show that the method of making bubbles rather than watching cartoons method has helped to reduce pain in children during chemotherapy $(\mathrm{p}<0 / 01)$.

Conclusion: Generally the results showed that the distraction includes none pharmacologic interventions are effective in pain relief. In addition this method has the little or even no complications than medicinal methods, and also has low cost. This method has no physical and psychological devastating effects for children, has easy application, requires less training and does not need a lot of time to execute for kids and more importantly is that this method is attractive to children and by using this children will have less perceived of pain. Finally the findings of this study suggest that the possibility of using distraction methods as effective non- Pharmaceutical treatments in different parts of the hospital will help to reduce pain.

Key words: Distraction Techniques, Children Suffering from Cancer, Chemotherapy, Pain Decrease.

\begin{tabular}{|l|l|}
\hline \multicolumn{3}{|c|}{ Access this article online } \\
\hline
\end{tabular}


دوره اول، شماره (، بهار وجسا، صفحات سז-10 مقايسه تكنيك هاى انحر اف فكر (تماشاى كارتون و ساخت حباب) در كاهش درد ناشى از شيمى

\section{درمانى در كودكان مبتلا به سرطان}

نيلوفر ميكاييلى'، افشين فتحى '، سارا كنعانى"، حميدرضا صمدى فرد٪"

ا- ا- دانشيار گروه روانشناسى، دانشعاه محقق اردبيلى، ايران.

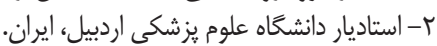

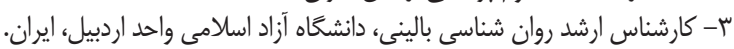

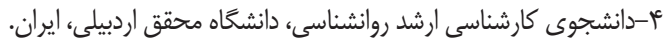

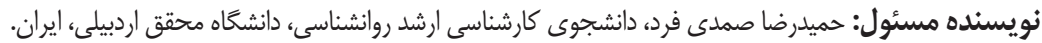

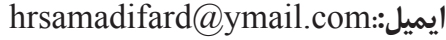

مقدمه: از جمله مداخلات دردناك درمانى كه در بيماران مبتلا به سرطان مورد استفاده قرار مى كيرد، شيمى درمانى است. هدف مطالعه مقايسه دو تكنيك انحراف فكر ديدارى (تماشاى كارتون) و ذهنى (ساخت حباب) در كاهش درد ناشى از شيمى درمانى در كودكان مبتال به سرطان بودان

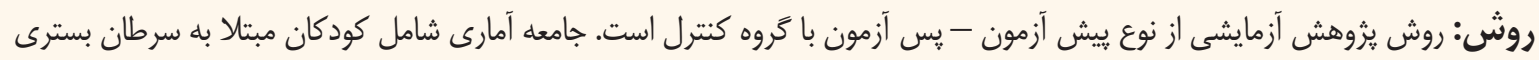

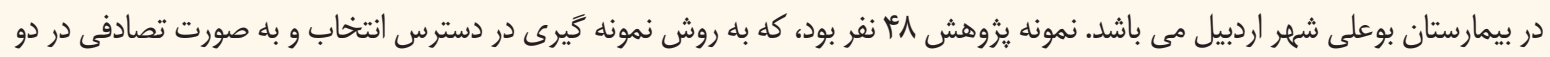

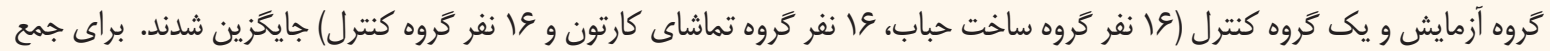

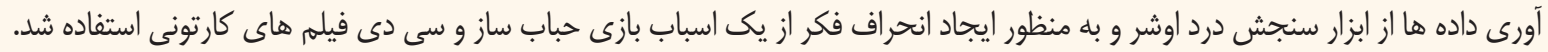
داده هاى ثروهش با استفاده از تحليل واريانس يك متغيرى تحليل شدند.

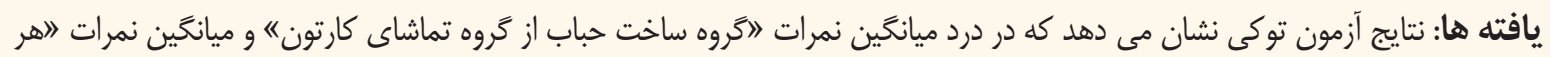

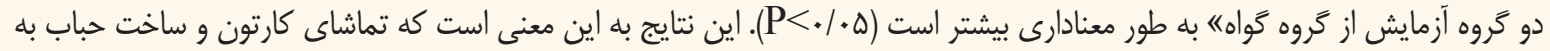

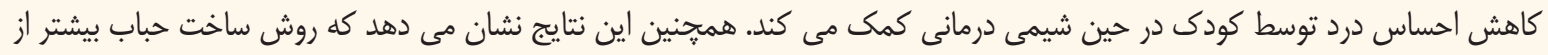

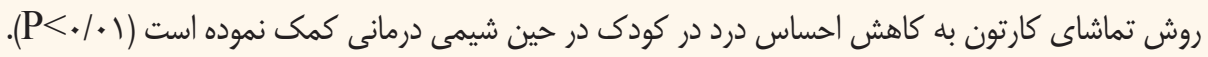

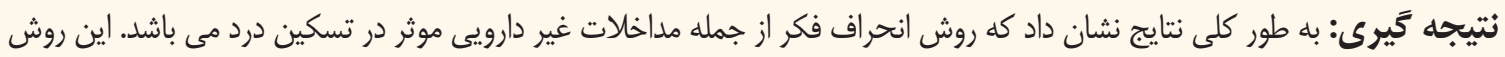

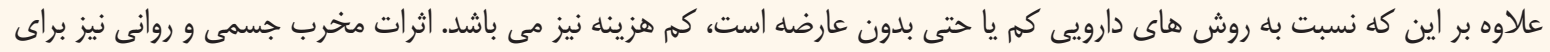

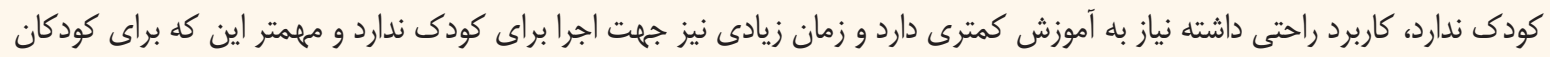

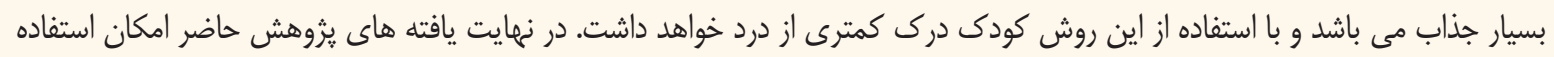

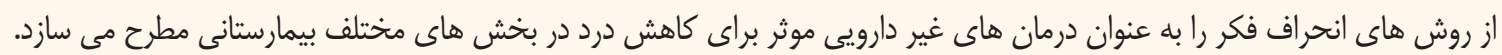

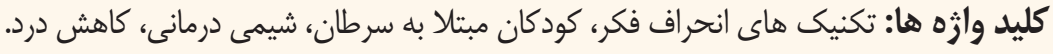




\section{نيلوفر ميكاييلى و همكاران}

متفاوتى نيز دارد. در سالمهاى اخير تأكيد زيادى بر روشهاى غير دارويى

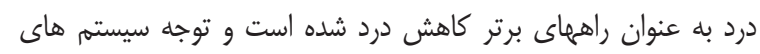

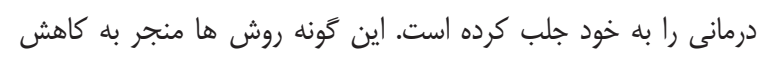

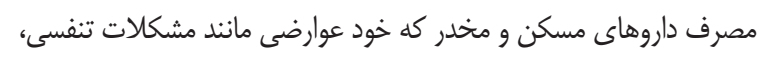

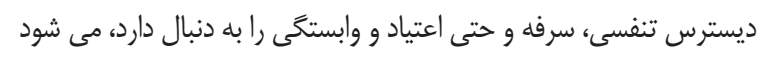

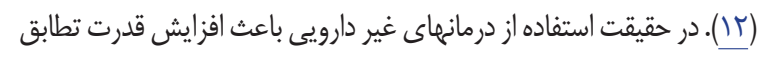

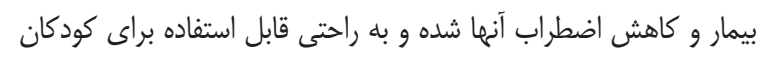

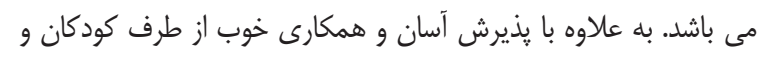

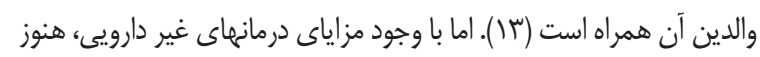

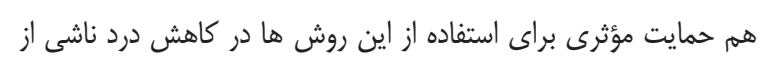

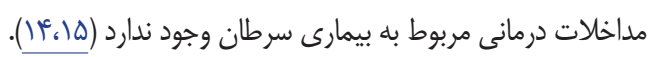

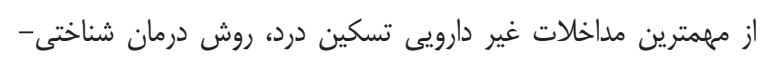

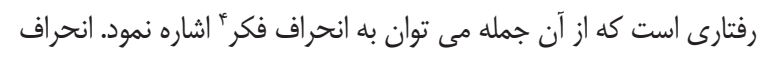

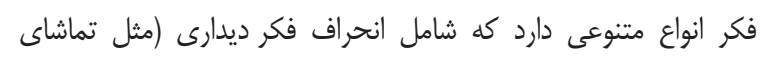

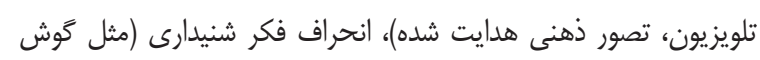

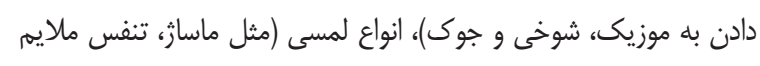

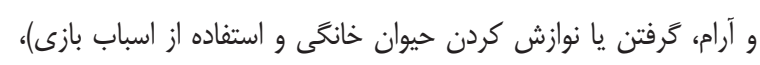

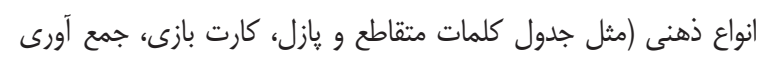

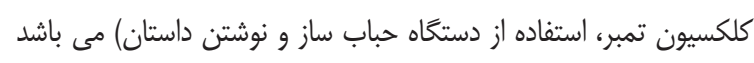

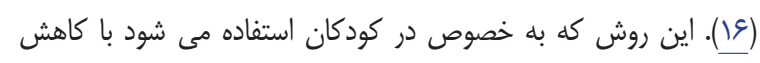

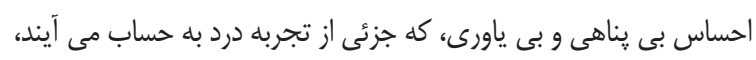

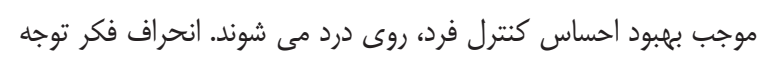

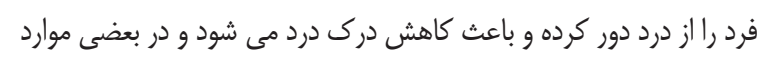

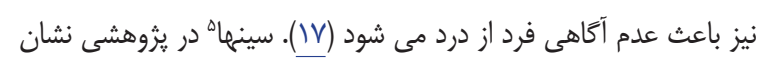

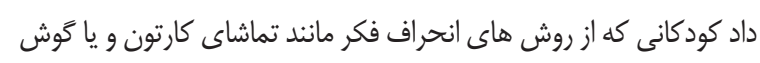

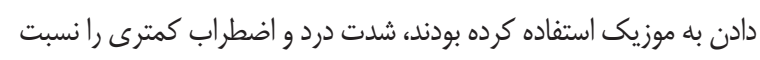

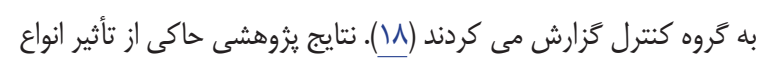

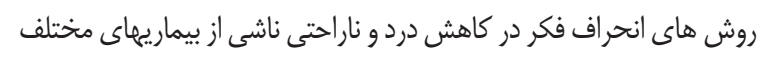

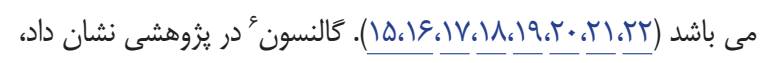
علائم مرضى كودكان داراى بيماريهاى جسمى و روانى از قبيل سرطان،

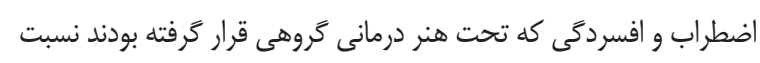

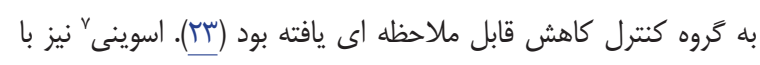

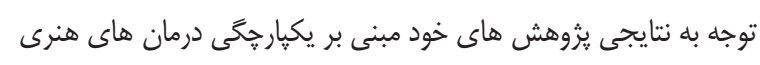

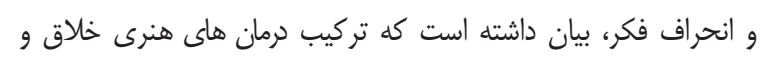

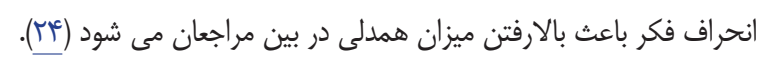

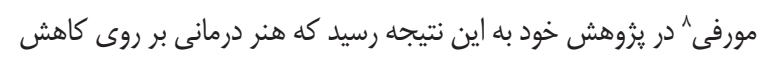

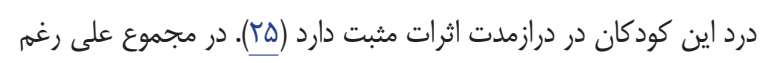

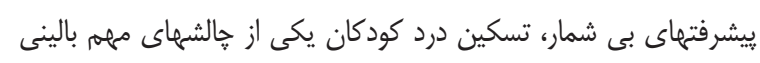

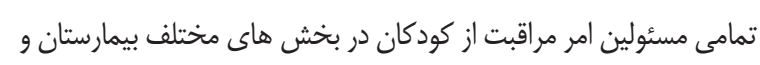

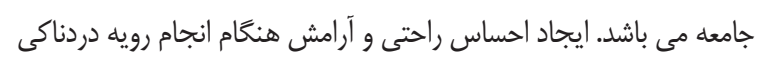


ه-نداشتن تشنج يا هر گَنه وضعيت اورزانسى تهلديد كننده زندگى (بيمارى قلبى يا تنفسى حاد و ... ) צ- عدم دريافت داروى مسكن قبل از شروع شيمى درمانى.

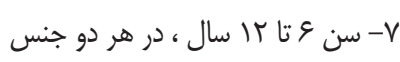
1- تكميل فرم رضايت از شركت در يزوهش توسط والدين ملاكى هاى خروج از مطالعه: 1- عدم همكارى كودى يا خانواده در هر يك از مراحل يزوهش. r-بى قرارى كودى و عدم تحمل شرايط يزوهش. براى جمع آورى داده ها در اين يثوهش از ابزار زير استفاده شد:

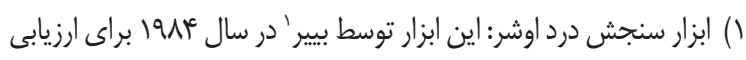

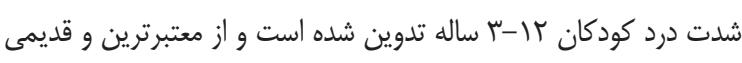
ترين و ير استفاده ترين مقياس هاى خود گزارش شدت درد است كه از جهره كودكان در موقعيت هاى دردناك استفاده مى نمايد. اين ابزار مورد

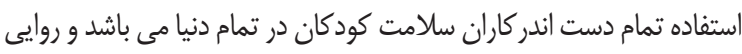
محتوايى وساختارى آن با آزمون هاى روايى و يايايى مستند شده است

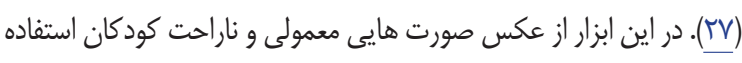
شده كه از جهره ى واقعى كودكان حين تجربه درد واقعى در بيمارستان

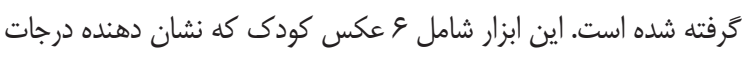
مختلف درد بوده و به صورت عمودى و بر اساس كمترين تا شديدترين درد

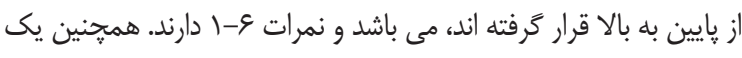

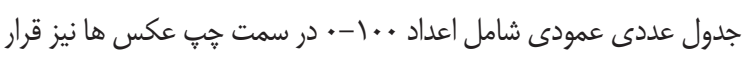
كرفته است. ميزان عددى براى كودكانى است كه قادر به شمردن هستند

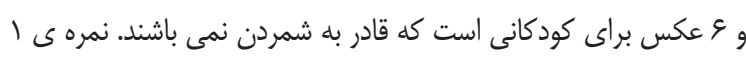

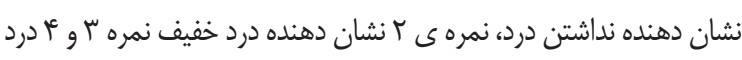

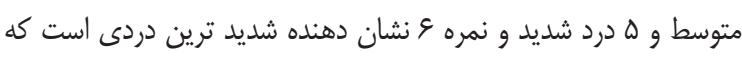
كودى تجربه نموده مى باشد (rV)

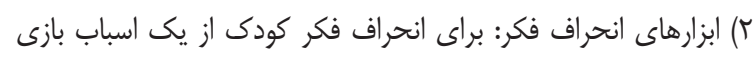
حباب ساز و نيز سى دى فيلم هاى كارتونى (يخش شده از صدا و سيماى كشور) استفاده شد.

روش كار به اين صورت بود كه بعد از فراهم كردن مجوزهاى لازم به مركز

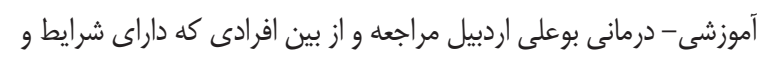

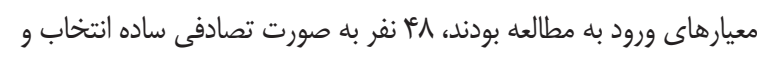
در دو گروه آزمايش و يك گروه كنترل گمارده شدند. قبل از شروع كار توضيحاتى در مورد اهداف يزوهش و نحوه كار به والدين

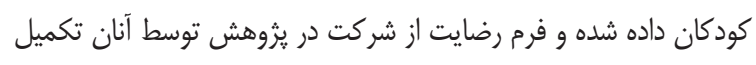

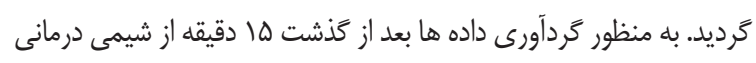
روى كودى و قبل از اين كه هيج مداخله ایى صورت گرفته باشد، درد

1- Byere
جون شيمى درمانى كه بر روى كودكان سرطانى انجام مى شود، امرى است

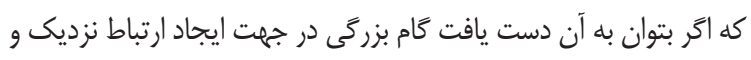

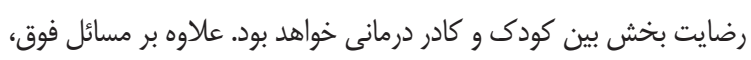

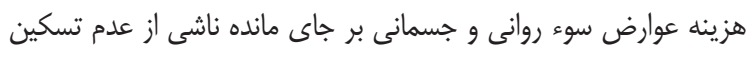
درد كودكان، استرس و ناساز كارى و ترس بسيار بالا در اعضا خانواده، انتقال

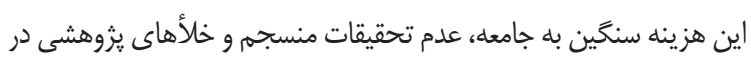

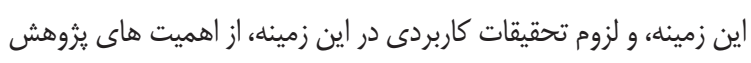

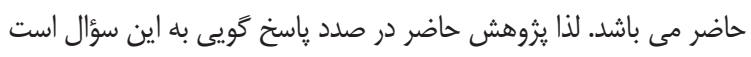

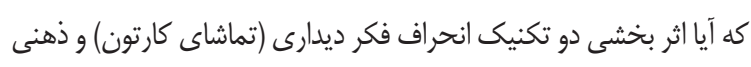

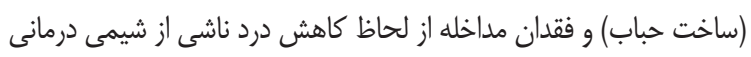

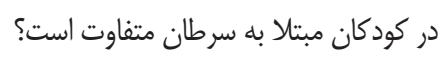

\section{روش مطالعه}

يزوهش حاضر يك مطالعه ى آزمايشى است كه با طرح ييش آزمون - يس

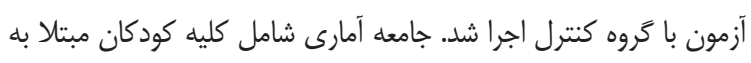
سرطان بسترى در بيمارستان بوعلى شهر اردبيل در سال •وس إ بودند. نمونه

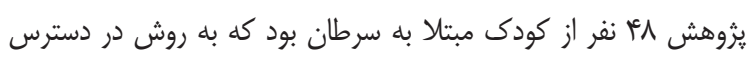

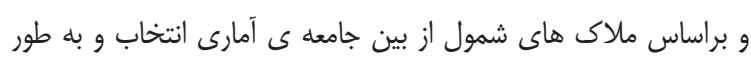

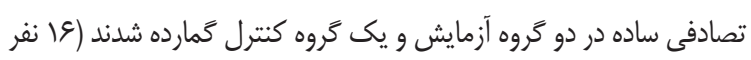
گروه آزمايش ساخت حباب، عا نفر گروه آزمايش تماشاى كارتون و و 19

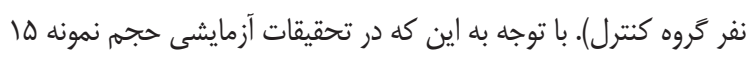

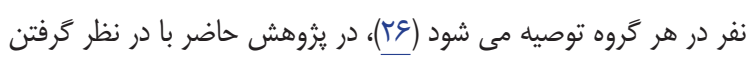

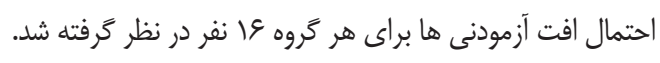

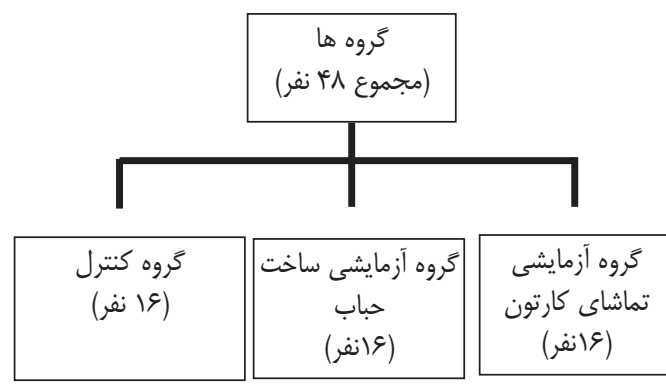

ملاك هاى ورود به مطالعه : 1- دستور بسترى در بخش انكولوزى (خون) اطفال.

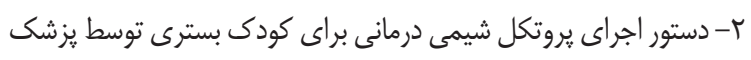

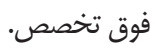
r- هوشيارى به زمان و مكان و شخص (با طرح سوالات شفاهى ييرامون تشخيص كودى در رابطه با زمان (شب و روز) مكان (حضور در بيمارستان) و شخص (شناسايى مادر) هوشيارى كودى بررسى شد).

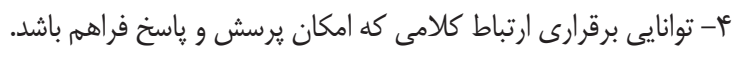


(أنوا) مورد تجزيه و تحليل آمارى قرار گرفنتن. لازم به ذكر است كه به منظور رعايت اخلاق حرفه اى براى كروه كنترل نيز پِّ از از اتمام يزوهش روش هاى انحراف فكر به كار رفت. همجنين كد هاى رائ رايج

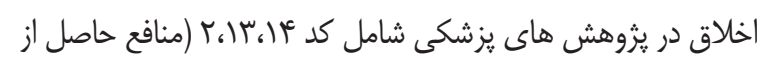

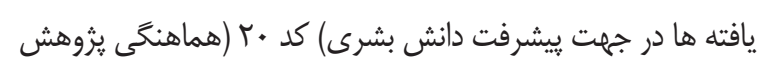

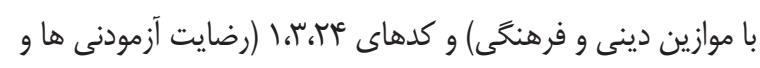

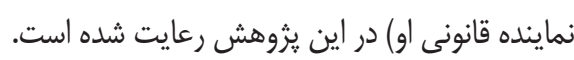

\section{يافته ها}

همانطور كه نتايج جدول شماره ا نشان مى دهد ميانكين و (انحراف

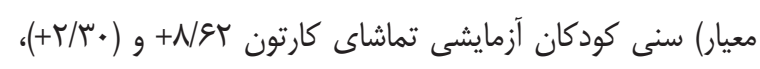

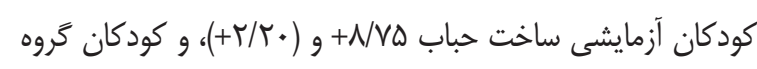

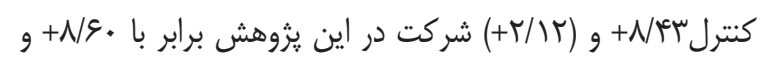

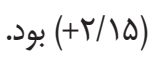

تصادفى ساده انتخاب و در دو گروه آزمايش و يك گروه كنترل

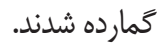

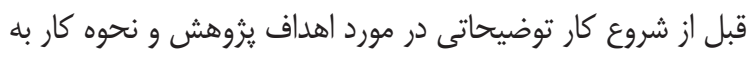

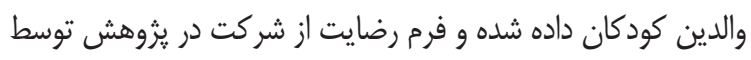

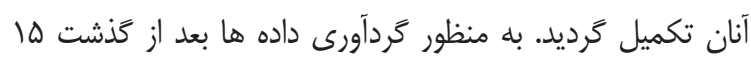
دقيقه از شيمى درمانى روى كودى و قبل از اين كه هيج مداخله دانه اى صورت كَرفته باشد، درد كودى توسط مقياس اوشر به به عنوان

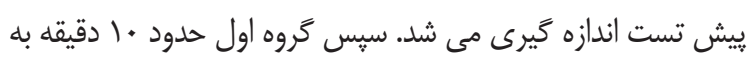

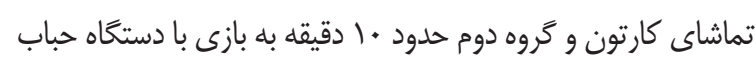

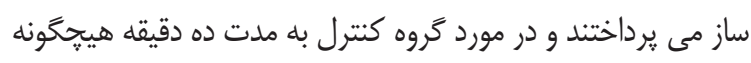

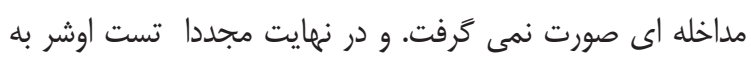

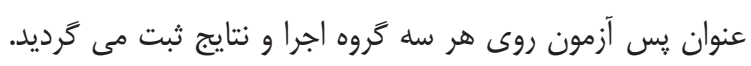

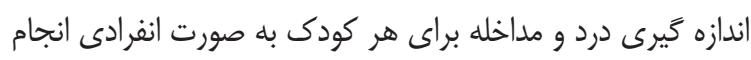

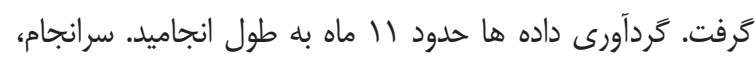

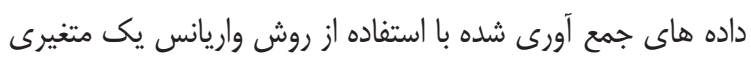
جدول (: ميانكين و انحراف استاندارد سن كودكان سرطانى در سه كَروه

\begin{tabular}{|c|c|c|c|c|}
\hline تعداد & انحراف معيار & ميانكين & تروهها & متغير \\
\hline 19 & $+r / \mu$. & $+N / g r$ & آزمايشى تماشاى كارتون & \\
\hline 19 & $+r / r$. & $+\Lambda / V \Delta$ & آَزمايشى ساخت حباب & \\
\hline 19 & $+t / T$ & $+\Lambda / F T$ & كنترل & سن \\
\hline$i \wedge$ & $+r / / Q$ & $+N / 8$. & كل & \\
\hline
\end{tabular}

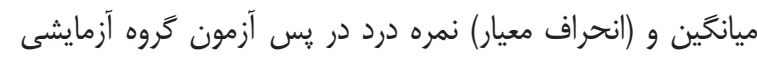

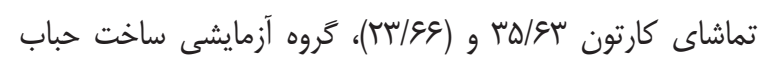

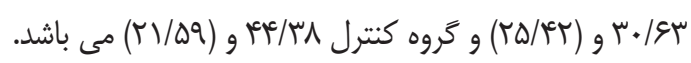

همانطور كه در جدول شماره r مشاهده مىشود ميانگين آنمان

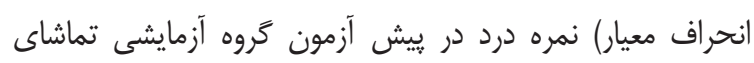

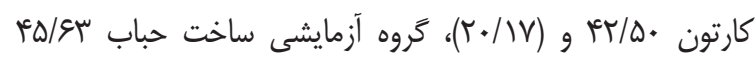

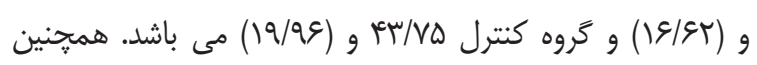

جدول ז: ميانكين و انحراف استاندارد متغير درد در كودكان سرطانى در ييش آزمون و يس آزمون

\begin{tabular}{|c|c|c|c|c|}
\hline \multicolumn{2}{|c|}{ گِ آزمون درد } & \multicolumn{2}{|c|}{ ييش آزمون درد } & \multirow{2}{*}{ تروه شاخص } \\
\hline انحراف معيار & ميانكَين & انحراف معيار & ميانتين & \\
\hline e & L & $+r \cdot / I V$ & $+F T / D$. & آزمايشى تماشاى كارتون \\
\hline$+T A / F T$ & $+\mu \cdot / q \mu$ & $+\mid 9 / 94$ & $+\lceil\Delta / q \mu$ & آزمايشى ساخت حباب \\
\hline$+r V / \Delta q$ & $+\mu k / \mu \Lambda$ & $+19 / 99$ & $+r \Psi / V \Delta$ & كنترل \\
\hline
\end{tabular}

اين بدين معنى است كه اثر بخشى دو روش انحراف فكر تماشاى

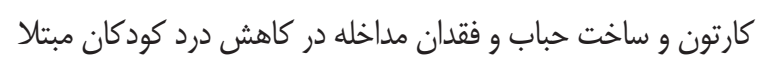
به سرطان در حين شيمى درمانى متفاوت است.
همان طور كه در جدول شماره ؟ مشاهده مى شود اين فرضيه كه

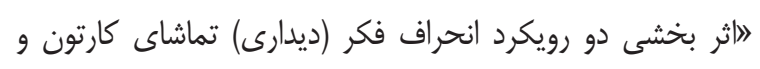
انحراف فكرى (ذهنى) ساخت حباب و فقدان مداخله از لحاظ كاهش

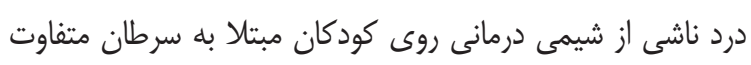

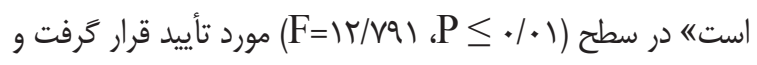


جدول س: تحليل واريانس يك طرفه متغير درد در كودكان سرطانى در سه كَوه

\begin{tabular}{|c|c|c|c|c|c|}
\hline سطح معنادارى & $\mathbf{F}$ & ميانكَين مجذورات & درجات آزادى & مجموع مجذورات & مدل \\
\hline.$/ . .1$ & $|r / V q|$ & $\begin{array}{l}+q V V / \cdot \Lambda \mu \\
+V \varepsilon / r \wedge q\end{array}$ & $\begin{array}{l}r \\
r \Delta \\
r v\end{array}$ & 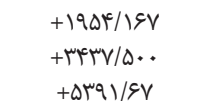 & درون كَروهى \\
\hline
\end{tabular}

معنى است كه تماشاى كارتون و ساخت حباب به كاهش احساس درد توسط كودى در حين شيمى درمانى كمك مى كند. همجنين اين نتايج نشان مى دهد كه روش ساخت حباب بيشتر از روش تماشاى كارتون به كاهش احساس درد در كودى در حين شيمى درمانى كمك نموده است.
براى مقايسه ميانگين نمرات متغير درد در سه گروه تماشاى كارتون،

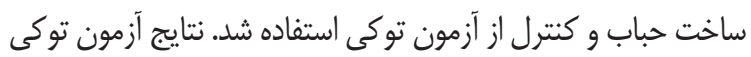
نشان مى دهد كه در درد ميانگين نمرات آگروه ساخت حباب از گروه تماشاى كارتون" و ميانخين نمرات لهر دو گروه آزمايش از گروه

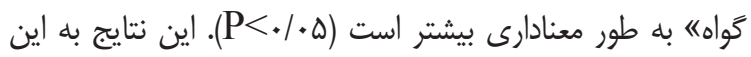

جدول ff: مقايسه ميانكَين نمرات متغير درد در سه كروه تماشاى كارتون، ساخت حباب و كنترل با آزمون توكى

\begin{tabular}{|c|c|c|c|c|c|c|c|}
\hline \multicolumn{2}{|r|}{ كنترل } & \multicolumn{2}{|c|}{ ساخت حباب } & \multicolumn{2}{|c|}{ تماشاى كارتون } & \multirow{2}{*}{ تروه } & \multirow[b]{2}{*}{ متغير } \\
\hline $\mathbf{P}$ & تفاوت ميانكَين ها & $\mathbf{P}$ & تفاوت ميانكين ها & $\mathbf{P}$ & تفاوت ميانكين ها & & \\
\hline.$/ .+4$ & $* V / \Delta$ & . & *-N/Ir & - & - & تماشاى كارتون & \\
\hline.$/ . \cdot 1$ & ****a & - & - &.$/ \cdot r$ & *N/IT & ساخت حباب & \\
\hline- & - & $.1 . .1$ & *****: &.$/ . k T$ & $*-V / \Delta$. & كنترل & درد \\
\hline
\end{tabular}

به تغيير در تجربه درد هستند. مكانيزم عمل اين روش ها به اين صورت است كه ايجاد انحراف فكر به وسيله محرك هاى خوشايند، باعث آزاد سازى اندروفين ها و در نتيجه كتترل درد مى گردد. مطابق اين تئورى در سيسته اعصاب مركزى گيرنده هاى إييوئيدى وجود

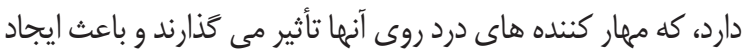

اعمال ضد درد مشابه مورفين مى شوند (rᄉ). روش هاى مختلف انحراف فكر باعث هدايت يا تغيير تمركز فرايندهاى توجهى يا عقايد و باورهاى شخص مى شوند. به طور

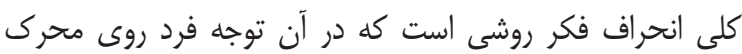
ها و فرايندهاى خارجى موجود در محيط متمركز مى شود و اين تمركز روى محرك ديخًى غير از درد، باعث تسكين احساس درد مى شود. كمبود يا فقدان تحريكات حسى متنوع، باعث مى شود كه

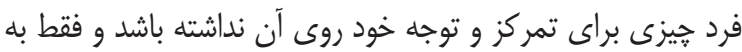
تحريكات دردناك توجه كرده و درد را شديد حس نمايد، در صورتى كه اگر براى فرد فعاليت هاى متنوعى مانند تماشاى كارتون فراهم

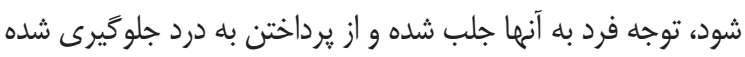

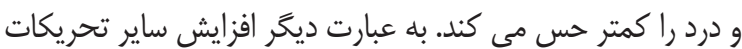
حسى به ويثه شنوايى، بينايى، لمسى و وضعيتى باعث از بين رفتن توجه فرد به درد مى شود. انحراف فكر مى تواند باعث تغيير واكنش

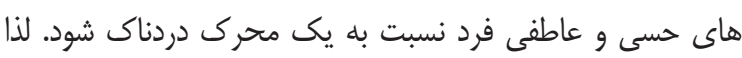

سالانه ץ تا ع كودى از هر صد هزار كودى در جهان به انواع سرطان ها مبتلا مىشوند. متأسفانه آمار دقيقى از ميزان شيوع سرطان

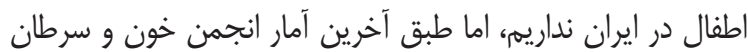

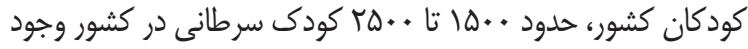
دارد (بِ). بنابراين هدف يُروهش حاضر مقايسه دو تكنيك انحراف فكر ديدارى (تماشاى كارتون) و ذهنى (ساخت حباب) و فقدان مداخله در كاهش درد ناشى از شيمى درمانى در كودكان مبتلا به سرطان بود. نتايج يزوهش حاضر نشان داد كه دو رويكرد تماشاى كارتون و ساخت حباب در كاهش درد ناشى از شيمى درمانى در

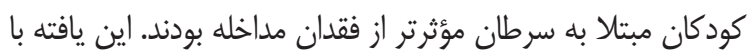

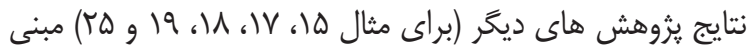
بر اثر بخشى رويكردهاى انحراف فكر در كاهش درد ناشى از شيمى درمانى و بيماريهاى مختلف همراستا مى باشد. در تبيين اين يافته مى توان كَفت روش هاى غير دارويى با كاهش احساس بى يناهى و بى ياورى كه جزئى از تجربه درد است، موجب بهبود احساس كنترل فرد روى درد مى گردد، همجنين موجب استقلال بيماران مى شود. ضمن اينكه اين شيوه ها موجب افزايش احساس خود كنترلى و

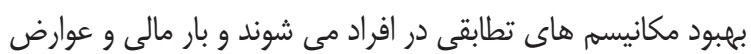
كمترى دارند. در واقع روش هاى شناختى از جمله انحراف فكر قادر 


\section{نيلوفر ميكاييلى و همكاران}

احساس درد توسط كودى در حين شيمى درمانى كمى مى كند.

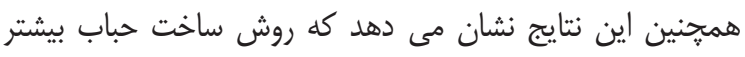

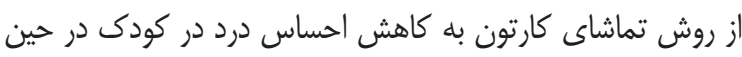
شيمى درمانى كمك نموده است. عدم كنترل نوع سرطان و نوع داروهاى مصرفى و لحاظ نكردن

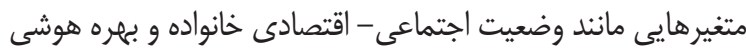

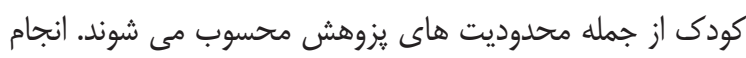

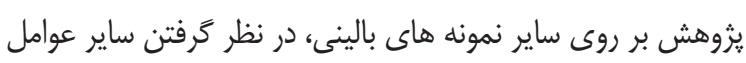
موثر بر احساس درد، تلفيق روشهاى انحراف فكر با روشهايى مانند هنردرمانى و انجام يِيخيرى هاى بعدى ضمن افزايش قابليت تعميم يذيرى نتايج به فهم بهتر موضوع كمك مى نمايد.

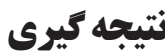

به طور كلى نتايج نشان داد كه روش انحراف فكر از جمله مداخلات

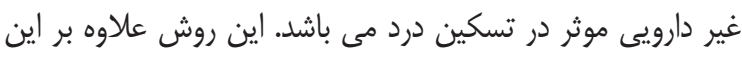

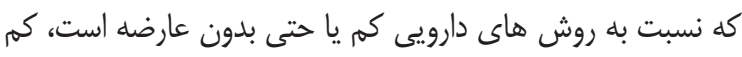

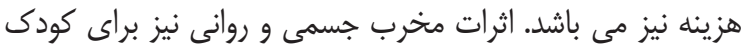

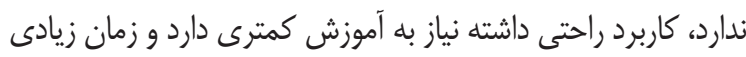

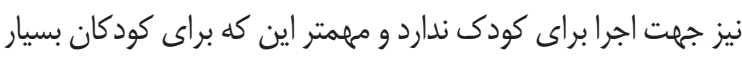

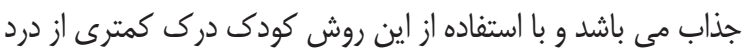
خواهد داشت (9)). در نهايت يافته هاى يثوهش حاضر امكان استفاده از روش هاى انحراف فكر را به عنوان درمان هاى غير دارويى موثر نائر براى كاهش درد در بخش هاى مختلف بيمارستانى مطرح مى ساز دان.

\section{تشكر و قدردانى}

بدينوسيله محققان مراتب تشكر و قدردانى صميمانه خود از مديريت

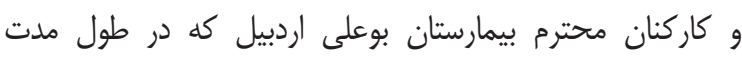
انجام يزوهش حاضر نهايت همكارى را با آنان داشته اند، اعلام

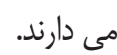

بيشتر توجيهات علمى در مورد اثر تسكينى انحراف فكر به دو دليل عمده توجه مى كند: الكَوى ظرفيت محدود و الكَوى كانون توجه اين تئوريها معتقدند كه يردازش اطلاعات در مغز داراى ظرفيت محدودي است و تعيين ارادى يك محرك به عنوان مركز توجه، باعث كاهش

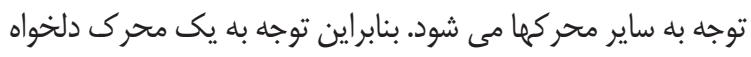
باعث كاهش ظرفيت درك فرايند درد مى شود، در نتيجه حساسيت

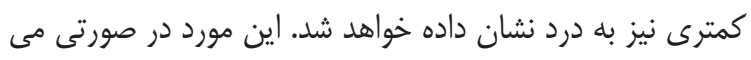

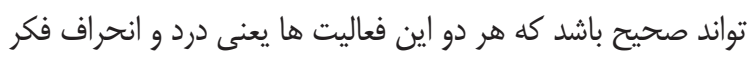
نياز به يردازش كنترل شده و اختصاص آكاهانه ذخيره حافظه كوتاه

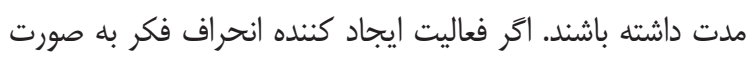

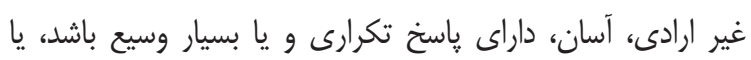

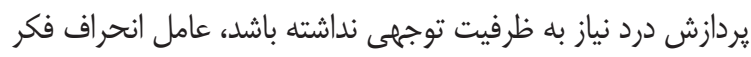

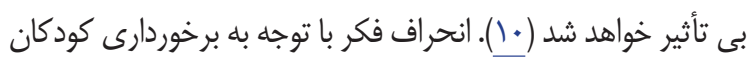

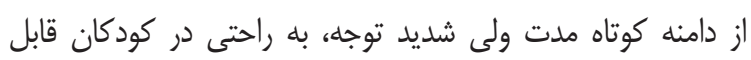

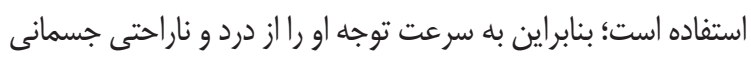
به حيز جالب، منحرف مى كند. كودكان تمايل و مهارت زيادى براى معطوف ساختن حواس خود به موضوعات ديخر دارند اغلب والدين و

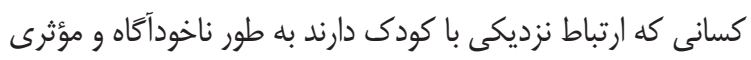
از اين روش جهت تسكين درد كودى استفاده مى كنند. براساس يافته هاى يزوهش اثر بخشى تكنيك انحراف فكر (ذهنى دردى ساخت حباب از اثر بخشى رويكرد انحراف فكر (ديدارى) تماشاى برى

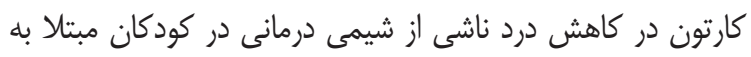

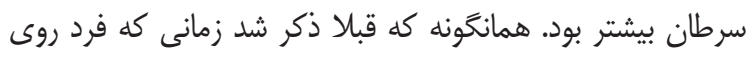

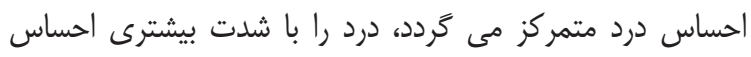

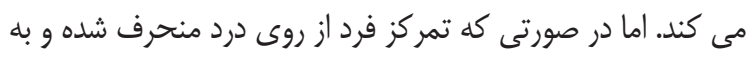

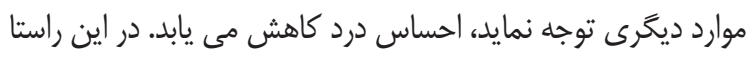

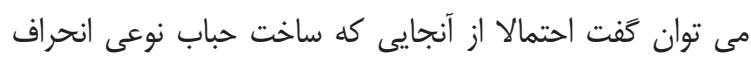

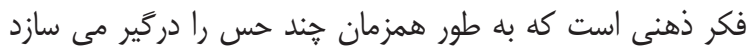

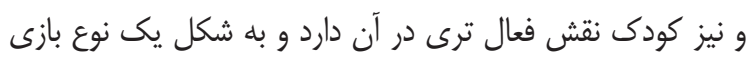

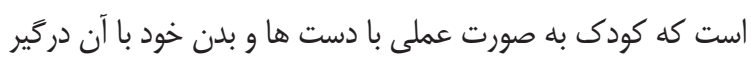

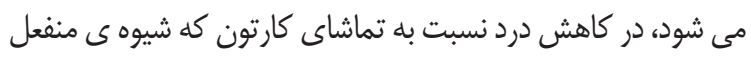
ترى است، اثر بخشى بيشترى دارد. در نهايت براى مقايسه ميانكَين نمرات متغير درد در سه كَروه تماشاى كارتون، ساخت حباب و كنترل از آزمون توكى استفاده شد. نتايج آزمون توكى نشان مى دهد كه در درد ميانكين نمرات الكروه ساخت

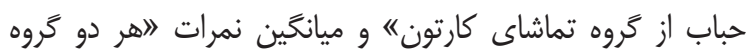

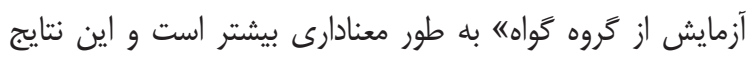

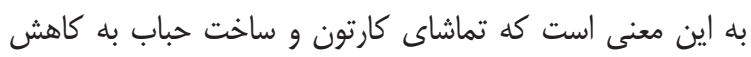




\section{References}

1. Kliegman $\mathrm{R}$, \& Behrman R, Nelson textbook of Pediatrics. Translated by Mohsen Arjmand and Aliraza Salekmoghadam. Tehran: Arjmand publications, 2010. [In Persian]

2. Abolghasemi H. Statement from the Children's Cancer Association and the Ministry of Health and Medical Education of Iran. Tehran; 2010. [In Persian]

3. Bijari H, Ghanbari Hashem Abadi BA, Hamidreza A, \& Homayi Shandiz F. Evaluation of a group therapy based on a Hope therapy approach on increasing the life expectancy of women with breast cancer. Journal of Educational Studies and Psychology 2009; 10 (1): 184-171. [In Persian]

4. White CA. Cognitive Behaviour Therapy for Chronic Medical Problems: A Guide to Assessment and Treatment in Practice; 2001. Translated by Reza Molavi and Katayoon Fattahi. Tehran: Arjmand publications; 2010.

5. Maani A. Traditional Psychological Medicine The psyche as pain and therapy. Shiraz University Press; 2007. [In Persian]

6. Sharifi M, \& Ordokhani A. Pain relief and maintenance care of cancer pain in children. Statement from the World Health Organization, Tehran; 2005. [In Persian]

7. Finly AG, Grath MC, Cambers P, Bringing C. Pain relief to children treatment approaches, New Jersey: human press; 2006.

8. Tavasoli H, Alhani S, Hajizadeh F. The relationship between anxiety and pain from injections in young children with thalassemia. Paper presented at the International Conference on Children. Tehran University of Medical Sciences; 2007. [In Persian]

9. Hocken BM, Willson DW. Essential of pediatric nursing. 8th ed. Stlouis: Mosby; 2007.

10. Valizadeh F. Comparison of the effects of two methods of distraction using music \& regular breathing $(\mathrm{He}-\mathrm{Hu})$ on the intensity of pain from venipuncture in 6 to 12 year-old children. Master's thesis, Shahid Beheshti University of medical sciences; 2000. [In Persian]

11. Tirgani E, \& Naseri A. Guidelines for the family physician. Tehran: Imamat publishers; 2008. [In Persian]

12. Elahi F. Chronic pain, nature, treatment, \& side effects. Tehran: Teymourzadeh Publications; 2001. [In Persian]

13. Shaban M, Rasoolzade N, Mehran A, \& Moradalizade F. Effect of two nonpharmacological methods (progressive muscle relaxation and music therapy) on pain intensity in cancer patients. Journal of Nursing and Midwifery, Tehran University of Medical Sciences (Hayat) 2006; 12(3): 63-72. [In Persian]

14. Bandstra NF, Skinner L, LeBlanc C, Chambers CT, Hollen EC, Brennan D, \& Beaver, C. The role of child life in pediatric pain management: A survey of child life specialists. The Journal of pain 2008; 9(4): 320-329.

15. Tak JH, Bon Van WHJ. Pain and distress reduction intervention for venepuncture in children. Child: care, health and development 2006; 32(3): 257-268.

16. Jacobson AF. Cognitive-Behavioral Interventions for IV insertion Pain. Aoren Journal 2006; 84(6): 1031-1048.

17. Vosoghi N. Effects of distraction on some physiological indicators and intensity of pain from venous catheter insertion in 3 to 6 year-old children. Master's Thesis, University of Guilan; 2008. [In Persian]

18. Sinha M, Christopher NC, Fenn R, \& Reeves L. Evaluation of no pharmacologic methods of pain and anxiety management for laceration in the Pediatric Emergency Department. Pediatrics 2006; 117: 1162-1168.

19. Shahabi M, Kalani Tehrani D, Eghbal M, Alavi Magd H, \& Aabed Saeidi Zh. A comparison of the effects of EMLA anesthetic cream and distraction (using music) on pain of venipuncture in school aged children at the Ayatollah Shahid Dastgheib Hospital Shiraz. Shahid Beheshti Journal of Nursing and Midwifery 2007; 17 (56): 12-18. [In Persian]

20. Perry P. Clinacsl nursing skills and techniques. Philadelphia: Mosby; 2006.

21. Friedrich WF. Art-therapy \& CBT in child abuse trauma, association for play therapy 2008; 17(1): 7-10.

22. Williams GH. Developmental Art Therapy. Baltimore, MD: University Park Press 2009.

23. Galenson D. Portraits of the Artist: Personal Visual Art in the Twentieth Century. University of Chicago - Department of Economics; National 


\section{نيلوفر ميكاييلى همكاران}

Bureau of Economic Research, NBER Working Paper 2009; No. W13939.

24. Sweeney DS, \& Homeyer L. The hand book of group play Therapy: how to do it, how it works, whom it's best for. Jossey-Bass Publishers; 1999.

25. Murphy J. Art therapy with sexually abused children and young people, International Journal of Art Therapy 2011; 3(1): 10-16.

26. Delavar A. Theoretical and practical research in the humanities and social sciences. Tehran: Roshd Publications; 2009. [In Persian]

27. Beyer JE. The alternate forms reliability of the oucher pain scale. Pain management nursing 2005; 6(1): 10-17.

28. Mcgrath PJ, \& Unguth AM. Pain measurement in children. Pain clinical update, 1995; 1 (2): 1-4.

29. Namnabati M. The effect of distraction on pain from burn injuries at the Hospital for burn trauma, Isfahan. Research in Medical Sciences. 2002; 7 (1):67-69. [In Persian]. 